Arch Virol (2000) 145: 2493-2502

Archives of
Virology
OSpringer-vertag 2000
Prined in Austria

\title{
Mutational analysis of the NIa protease from pepper vein banding potyvirus
}

\author{
J. Joseph and H. S. Savithri \\ Department of Biochemistry, Indian Institute of Science, Bangalore, India
}

Accepted June 16, 2000

\begin{abstract}
Summary. The nuclear inclusion protein a (NIa) protease plays an important role in the life cycle of potyviruses by processing the viral polyprotein into functional proteins. For functional characterization, the NIa protease from Pepper vein banding potyvirus (PVBV) was overexpressed in Escherichia coli and purified. Using a recombinant polyprotein substrate containing the nuclear inclusion protein $b$ (NIb)-coat protein (CP) cleavage site, a trans-cleavage assay was developed for the NIa protease. The polyprotein substrate also possessed the cleavage site between NIa and NIb, in addition to the NIb-CP site. However, no trans-cleavage by the NIa protease between NIa and NIb was detected indicating that the cleavage between NIa and NIb under natural conditions would be by a cis-cleavage reaction. Site-specific mutations of the conserved residues D81, D90, C110, T146, $\mathrm{C} 151$ and $\mathrm{H} 167$ were performed to investigate their roles in the catalytic process of the protease. Such an analysis has revealed that D81 and C151 constitute two of the catalytic triad residues in the NIa protease, D90 and C110 are not essential for catalysis, and T146 and H167 are probably involved in binding to Gln at the $\mathrm{P} 1$ position of the substrate.
\end{abstract}

\section{Introduction}

Proteases play an important role in the life cycle of many viruses and share many similarities with their cellular counterparts [12]. The plant potyviruses contain an RNA genome encoding a single polyprotein that is processed by three viral proteases [24]. The P1 and HC-Pro are proteases with cis-cleavage activity releasing themselves from the polyprotein $[7,29]$. The NIa protease is involved in the cleavage of the remaining two-thirds of the polyprotein in cis- and trans-cleavage reactions [4]. There are at least six cleavage sites in the viral polyprotein recognized by the NIa protease $[5,14]$, which are defined by a consensus heptapeptide sequence $[6,10,13]$. The NIa protease has been shown to cleave the peptide bond C-terminus to a Gln or Glu at the P1 position in the heptapeptide sequence $[10,24]$. 
Molecular modeling studies by Bazan and Fletterick [2, 3] and Gorbalenya et al. [15] indicated that the potyvirus NIa protease possessed structural motifs shared with cellular serine proteases, with the substitution of Ser by a Cys as the active site nucleophile. This NIa-protease's counterparts in other viral systems are the picornaviral $3 \mathrm{C}$ protease and the comovirus $24 \mathrm{kDa}$ protease [12]. Mutational and three-dimensional structural analyses of picornaviral $3 \mathrm{C}$ proteases confirmed the structural and functional similarities between the $3 \mathrm{C}$ protease and cellular serine proteases $[1,8,20]$.

The NIa proteases from Tobacco etch potyvirus (TEV) and Turnip mosaic potyvirus (TuMV) have been overexpressed and purified [17, 22] and the recombinant proteases were shown to be catalytically active. However, a truncated NIa protease lacking the C-terminal 20-24 amino acids, resulting from autocatalytic activity of the recombinant protease, was less active [17, 18, 22]. Earlier mutational studies on TEV NIa protease indicated that His 46, Asp 81 and Cys 151 constitute the catalytic triad $[11,14]$. Attempts to delineate the region involved in substrate binding revealed that the C-terminal 150 amino acid residues of the NIa protease contained the necessary information for recognition of the cleavage site, and the specificity determinants were confined to at least three sub-domains (between amino acids 94 to 166, 166 to 183 and 183 to 243) of the TEV NIa protease [21]. However, specific amino acid residues involved in substrate recognition could not be identified. In the present work, a mutational approach was used to investigate the importance of different conserved residues in substrate binding and catalysis using Pepper vein banding potyvirus (PVBV) NIa protease as the model system.

Earlier, we had reported the purification and characterization of PVBV and showed that it was a distinct member of the genus Potyvirus [16, 23]. The NIa protease of PVBV showed 50 and $47 \%$ identity with TuMV and TEV NIa protease, respectively. In order to evaluate the role of some of the residues conserved in the NIa proteases of the members of the genus Potyvirus such as D81, D90, C110, T146, C151 and H167 in the function of the NIa protease, these residues were targeted for mutagenesis. In this paper, we report the overexpression, purification and characterization of PVBV NIa protease and its mutants. An in vitro immunoblot assay was developed for the recombinant NIa protease, and was used for the mutational analysis of the protease to determine the importance of different conserved amino acid residues in the catalytic activity of the enzyme.

\section{Materials and methods}

\section{PCR amplification and cloning of the NIa protease gene}

From the cDNA clone pPV229, which contains a $3.9 \mathrm{~kb}$ fragment comprising the $3^{\prime}$-end of PVBV genome [16], the NIa protease coding region was amplified by PCR using a pair of primers representing the $\mathrm{N}$ - and $\mathrm{C}$-termini of the protease.

(i) 5' AGTGGATCCATGGCCCGCTCGTTAAATAGA 3' (sense)

(ii) $5^{\prime}$ ATTGAATTC 
The italicized nucleotides represent $B a m \mathrm{HI}$ and $E c o$ RI restriction sites in sense and antisense primers, respectively. The underlined nucleotides, the start and stop codons in sense and antisense primers, respectively, were introduced for the overexpression of NIa protease in E. coli.

The PCR was performed for 30 cycles $\left(94^{\circ} \mathrm{C}, 1 \mathrm{~min}\right.$ for melting, $55^{\circ} \mathrm{C}, 1 \mathrm{~min}$ for annealing, $72^{\circ} \mathrm{C}, 1 \mathrm{~min}$ for polymerization) using Vent DNA polymerase (New England Biolabs, Inc., MA), and pPV299 as the template. Fifty ng of the template and 25 pmoles each of the above primers were used in a $100 \mu \mathrm{l}$ reaction volume. The PCR product was sequenced to confirm its integrity, and was cloned at the $P v u I I$ site of pRSET C expression vector (pRNIa).

\section{Site-directed mutagenesis}

Site-directed mutagenesis of the NIa protease was performed essentially by the megaprimer method [19] with some modifications. The following primers were used for obtaining the mutant constructs.

i. D81N : 5' GAGCAGAATATTATGTTTCTC $3^{\prime}$ (antisense)

ii. D90A : $5^{\prime}$ TGGTGGGA $A \bar{G} C C T$ TTGGAAG $3^{\prime}$ (antisense)

iii. C110A: 5' GCCAACTAAGGCAATTGAATC $3^{\prime}$ (antisense)

iv. T146I : 5' TGGATTGATATCAAGGATGGA 3' (sense)

v. C151A: 5' GATGGACACGCTGGCTTGCCA 3' (sense)

vi. H167Y: 5' GTTGGGTTTTACAGTCTCACA 3' (sense)

The underlined nucleotides represent the changes introduced to obtain the desired mutations and to engineer restriction sites for primary screening of the mutants. The italicized nucleotides represent restriction sites, SspI, StuI, MfeI and EcoRV for D81A, D90A, C110A and T146I, respectively.

The mutants were screened for the presence of desired mutations, initially by restriction analysis wherever possible, and confirmed by DNA sequencing [26].

\section{Expression and purification of the recombinant NIa protease}

For overexpression of the recombinant protease, one per cent of an over-night grown culture of $E$. coli BL-21 (DE3) cells, harboring pRNIa, was inoculated to $500 \mathrm{ml}$ Luria-Bertani (LB) medium containing $50 \mu \mathrm{g} / \mathrm{ml}$ of ampicillin. After $5 \mathrm{~h}$ of growth at $37^{\circ} \mathrm{C}$, the protein expression was induced by the addition of IPTG to a final concentration of $0.3 \mathrm{mM}$ and the cells were further grown for $4 \mathrm{~h}$ at $37^{\circ} \mathrm{C}$. The cells were harvested, resuspended in $40 \mathrm{ml}$ extraction buffer $(0.1 \mathrm{M}$ Tris- $\mathrm{HCl}, \mathrm{pH} 7.5$ containing $0.3 \mathrm{M} \mathrm{NaCl})$ and were sonicated using a Vibra cell sonicator. The supernatant was mixed with buffer-equilibrated Ni-NTA agarose beads at $4{ }^{\circ} \mathrm{C}$ for $1 \mathrm{~h}$. The beads were then loaded onto a column and were washed with $50 \mathrm{ml}$ each of washing buffers, A ( $0.1 \mathrm{M}$ sodium phosphate, $\mathrm{pH} 7.0$ containing $10 \%$ glycerol, $0.3 \mathrm{M} \mathrm{NaCl}$ and $50 \mathrm{mM}$ imidazole $)$ and $\mathrm{B}(0.1 \mathrm{M}$ sodium phosphate, $\mathrm{pH} 7.0$ containing $10 \%$ glycerol and $50 \mathrm{mM}$ imidazole). The proteins were eluted with $0.1 \mathrm{M}$ sodium phosphate buffer (containing 10\% glycerol and $250 \mathrm{mM}$ imidazole). The fractions containing the NIa protease were pooled and subjected to centrifugation in a centricon (Amicon Inc., Beverly, MA) to concentrate the protease. The concentrated protease was aliquoted and stored at $-20^{\circ} \mathrm{C}$.

For the mutant proteases, the same procedure was followed for overexpression and purification except that the cells were grown and induced at $30^{\circ} \mathrm{C}$, as it improved the solubility of the expressed mutant proteins.

\section{Expression of the NIb-CP substrate}

For cloning into expression vector, the NIb-CP fragment (containing the nucleotide sequence corresponding to C-terminal 9 aminoacids of NIa protease, NIb, CP and the $3^{\prime}$ untranslated 
region) was released from pPV229 clone by EcoRV and SmaI restriction digestion. The fragment was purified by low-melting agarose method [25] and cloned at the $P v u I I$ site of pRSET C to obtain pRNIb-CP. The construct was transformed into E. coli BL 21 (DE3) cells, and cultured and induced as described for the NIa protease except that the cells were grown in $10 \mathrm{ml} \mathrm{LB}$. After induction, the cells were harvested and resuspended in $4 \mathrm{ml}$ of Tris- $\mathrm{HCl}$ buffer $(0.1 \mathrm{M}, \mathrm{pH} 7.5)$ and lysed by sonication. The total protein was used for the protease assay.

\section{NIa protease assay}

In vitro cleavage assays for the NIa protease and the mutants were carried out in a $50 \mu 1$ reaction volume, in $50 \mathrm{mM}$ HEPES, pH $7.5,50 \mathrm{mM} \mathrm{KCl}$ with $1 \mu \mathrm{l}$ of NIb-CP substrate and $1 \mu \mathrm{g}$ NIa protease or mutants. The reaction mixture was incubated at $16^{\circ} \mathrm{C}$ for $6 \mathrm{~h}$ and the cleavage products were separated by $12.5 \%$ sodium dodecylsulfate-polyacrylamide gel electrophoresis (SDS-PAGE) and were transferred to nitrocellulose membrane. The release of the $\mathrm{CP}$ from NIb-CP by the protease was monitored by Western blot analysis using polyclonal antisera specific to the PVBV CP.

\section{Results and discussion}

Expression of the NIa protease in $\mathrm{E}$. coli

The NIa protease gene was PCR-amplified and cloned in pRSET C expression vector as described in the Materials and methods section. The cloning strategy results in the addition of 45 amino acids (41 from pRSET $\mathrm{C}$ vector and 4 from the sense primer) to the $\mathrm{N}$ terminus of the recombinant NIa protease. The NIa protease was overexpressed in E. coli to nearly $50 \%$ of the total proteins and most of it was present in the soluble fraction. As the recombinant protease contained His-tag at the $\mathrm{N}$ terminus, the protein could be purified by Ni-NTA agarose affinity chromatography. Single step purification yielded almost homogenous preparation of the recombinant protein (Fig. 1).

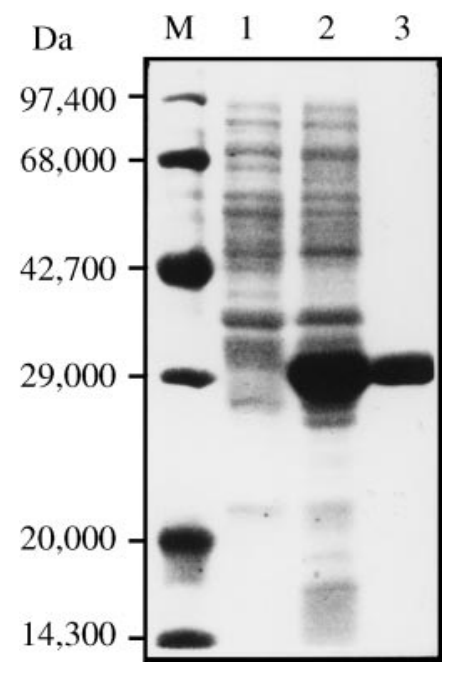

Fig. 1. SDS-PAGE analysis of recombinant PVBV NIa protease. E. coli BL 21 (DE3) cells harboring pRNIa were induced with $0.3 \mathrm{mM}$ IPTG. Total proteins $(\sim 50 \mu \mathrm{g})$ from uninduced ( 1 ) and induced (2) cells were separated by $12.5 \%$ SDS-PAGE and stained with Coomassie Brilliant Blue. $M \mathrm{M}_{r}$ markers; 3 NIa protease purified by Ni-NTA affinity chromatography 


\section{Expression of NIb-CP in $\mathrm{E}$. coli and NIa protease assay}

In earlier studies, the activity of the recombinant NIa protease was assayed using a peptide containing the cleavage site and by the use of polyprotein substrates obtained by in vitro translation [5, 17, 18, 22]. Hence, a nonapeptide (Ac-GGEVAHQAG-NH $\mathrm{H}_{2}$ ) corresponding to the cleavage site between the PVBV $\mathrm{NIb}$ and $\mathrm{CP}$ was synthesized, and was used as a substrate for the NIa protease. However, the attempt was not successful, as the cleavage products could not be detected when monitored by HPLC analysis (data not shown).

Alternatively, the NIb-CP polyprotein substrate was overexpressed in E. coli as described in Materials and methods. However, although the NIb-CP could be induced to a high level, the protein was insoluble (data not shown). Our attempts to solubilize the $\mathrm{NIb}-\mathrm{CP}$ were unsuccessful. We have, therefore, used the crude total protein extract from the induced cells harboring $\mathrm{pRNIb-CP}$ construct for assaying NIa protease activity. The cleavage by the protease of the NIb-CP substrate (97 $\mathrm{KD})$ to release $\mathrm{CP}(34 \mathrm{KD})$ was monitored by western analysis using PVBV CP-specific antiserum.

The conditions for the assay were optimized, by varying the parameters such as substrate and enzyme concentrations, $\mathrm{pH}$, time and temperature. The NIa protease showed optimal activity in HEPES buffer $(0.05 \mathrm{M}, \mathrm{pH} 7.5)$, at $16^{\circ} \mathrm{C}$ in the presence of $50 \mathrm{mM} \mathrm{KCl}$ (Fig. 2). An additional protein band corresponding to about $50 \mathrm{kDa}$ was observed even in the absence of NIa protease (Fig. 2, lane 1). This could be because of the proteolytic degradation of the substrate in E. coli or the presence of an internal initiation site for translation [13]. Earlier studies on NIa protease used the in vitro translated polyprotein substrates. Here we demonstrate that a simple immuno analysis can be used to monitor the trans-cleavage activity of NIa protease.

The EcoRI-SmaI fragment from pPV229, used for cloning NIb-CP into pRSET $\mathrm{C}$ expression vector, contains an additional nucleotide sequence encoding the

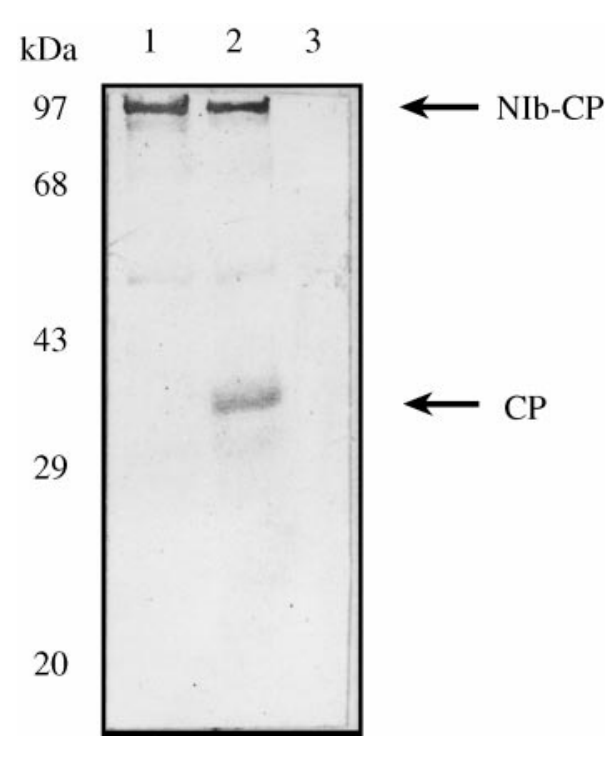

Fig. 2. Western blot showing the NIa protease activity using NIb-CP as the substrate. Total protein extract $(1 \mu \mathrm{l})$ from induced BL21 cells harboring pRNIb-CP construct was incubated with purified NIa protease $(1 \mu \mathrm{g})$ in $50 \mathrm{mM}$ HEPES buffer, $\mathrm{pH} 7.5$, containing $50 \mathrm{mM} \mathrm{KCl}$, for $6 \mathrm{~h}$ at $16^{\circ} \mathrm{C}$ and the products were analyzed by Western blotting with PVBV CP-specific antiserum (1:2000 dilution). 1 NIb-CP without NIa protease; 2 NIb-CP with NIa protease; 3 NIa protease alone 
C-terminal 9 amino acids of NIa protease. The expressed protein thus has the cleavage site between NIa and NIb, in addition to the NIb-CP site. If the NIa-NIb site were to be cleaved by the NIa protease in trans, it would result in a protein product of about $91 \mathrm{kDa}$ and a $6 \mathrm{kDa}$ fragment (45 amino acids from vector and 9 amino acids from $\mathrm{C}$-terminus of NIa protease). In the cleavage reaction, however, no trans-cleavage between NIa and NIb could be detected as a band corresponding to $91 \mathrm{kDa}$ was not detected (Fig. 2). Such a trans-cleavage was not observed for PPV NIa protease also [13]. This suggests that the cleavage between NIa and $\mathrm{NIb}$ would be by a cis-cleavage reaction under in vivo conditions. An increased time duration for proteolysis did not result in complete cleavage of NIb-CP, indicating that all the NIb-CP molecules would not be used as the substrate (data not shown). This would be because of the insoluble nature of NIb-CP and probably only a portion of it could be accessible as the substrate for NIa protease.

\section{Inhibition studies}

Earlier studies had demonstrated that $\mathrm{Zn}$ and cysteine-modifying agents such as N-ethyl malemide (NEM) and iodoacetamide inhibited the NIa protease activity [11]. In order to study the effects of different ligands $(10 \mathrm{mM} \mathrm{MgCl}, 10 \mathrm{mM}$ $\mathrm{ZnCl}_{2}, 1 \mathrm{mM}$ PMSF and $1 \mathrm{mM} \mathrm{NEM}$ ) on the protease activity, the reaction was carried out in the presence of these ligands. The NIa protease activity was inhibited by $\mathrm{Zn}$ and NEM as expected for enzymes with a cystine residue at the active site, whereas, other ligands had no effect on the protease activity (Fig. 3).

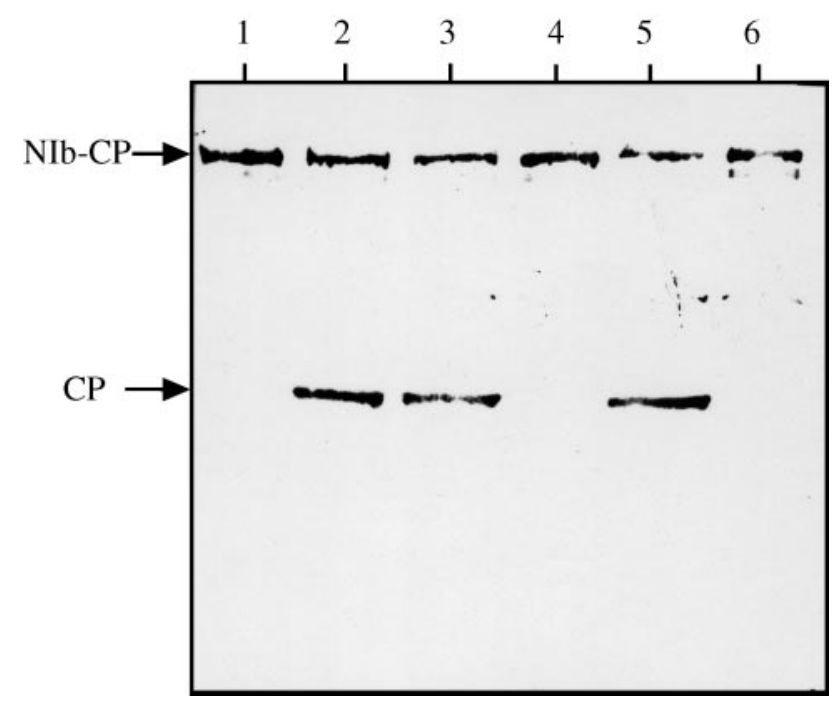

Fig. 3. Inhibition studies of NIa protease activity. NIa protease activity was monitored as described in legends for Fig. 2, in the presence of $10 \mathrm{mM} \mathrm{MgCl}_{2}$ (3), $10 \mathrm{mM} \mathrm{ZnCl}_{2}$ (4), $1 \mathrm{mM}$ PMSF (5) and $1 \mathrm{mM}$ NEM (6). 1 NIb-CP without NIa protease; 2 NIb-CP with NIa protease in the absence of added ligands 


\section{Characterization of the NIa protease mutants}

The effect of different amino acid substitutions by site-directed mutagenesis of the PVBV NIa protease was investigated using the in vitro assay system. Earlier mutational studies indicated that H46, D81 and C151 formed the catalytic triad $[11,14]$. Amino acid sequence comparison of the NIa proteases of different potyviruses showed that other than the proposed catalytic residues, D81 and C151, D90 and C110 were also conserved. Therefore, in order to study the importance of these residues, in addition to D81 and C151 (proposed catalytic residues) in the activity of the PVBV NIa protease, site-specific mutagenesis of the protease was performed for all these residues. The residues D81, D90, C110 and C151 were mutated to an Asn, Ala, Ala and Ala, respectively.

Earlier reports show that similar to the NIa protease, the picornavirus $3 \mathrm{C}$ protease also cleaves the peptide bond C-terminally to a conserved Gln or Glu in the cleavage recognition site [27, 28]. Three-dimensional structures of two picornavirus $3 \mathrm{C}$ proteases have been determined $[1,20]$. In the case of human rhinovirus (HRV) 3C protease, molecular modeling studies using a peptide substrate ( 8 amino acids) encompassing the cleavage site showed that T141 and H160 would be involved in the binding of Gln at the P1 position of the substrate [20]. The residues T146 and H167 represent the corresponding residues in potyviral NIa protease $[3,12]$. The residues T146 and H167, therefore, were mutated to Ile and Tyr, respectively, in order to study their role in the catalytic process.

All the mutant proteases were expressed at $30^{\circ} \mathrm{C}$ and purified as described for the wild-type NIa protease using Ni-NTA affinity chromatography. The mutant protease activity was studied using the in vitro assay system (Fig. 4). The D90A

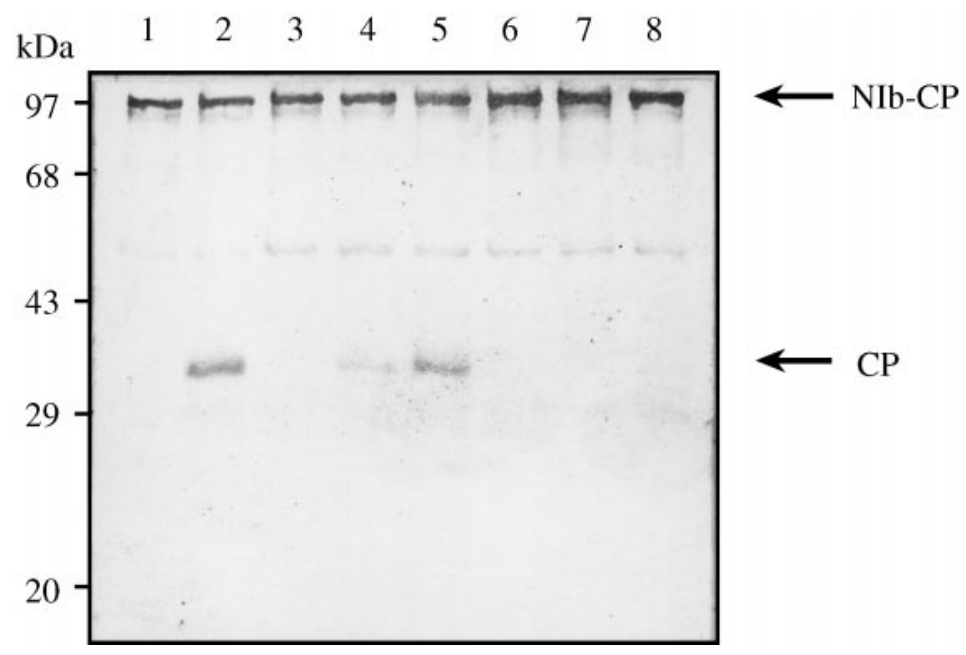

Fig. 4. Western blot showing the activity of the NIa protease mutants. Total protein extract $(1 \mu \mathrm{l})$ from induced BL 21 (DE3) cells harboring pRNIb-CP was incubated with the purified NIa protease mutants $(1 \mu \mathrm{g})$ in $50 \mathrm{mM}$ HEPES buffer, $\mathrm{pH} 7.5$, containing $50 \mathrm{mM} \mathrm{KCl}$, for $6 \mathrm{~h}$ at $16^{\circ} \mathrm{C}$ and analyzed as described in the legends for Fig. 2. 1 Without NIa protease; 2 with NIa protease; 3 D81N; 4 D90A; 5 C110A; 6 T146I; 7 C151A, 8 H167Y mutants 
and C110A mutants were catalytically active (lanes 4 and 5, respectively), whereas mutations of D81, T146, C151 and $\mathrm{H} 167$ rendered the protease inactive (lanes 3, 6,7 and 8, respectively). Similar results were obtained even when higher amounts of the mutants ( $5 \mu \mathrm{g}$ each) were used for the assay (data not shown).

These results are consistent with the earlier mutational analysis of TEV NIa protease, which showed that D81 and C151 would constitute two of the catalytic triad residues in NIa protease $[11,14]$. The residues D90 and C110 may not have a direct role to play in the catalysis process per se. Further these residues are conserved only in the poty virus genus but not across Potyviridae family.

Mutation of T146 and H167 of PVBV NIa protease however, resulted in inactive mutants (Fig. 4; lane 6 and 8), and in the light of the analysis of the picornaviral $3 \mathrm{C}$ proteases, we propose that these residues may be involved in the binding of Gln at the P1 position. Secondary structure prediction [9] of the PVBV NIa protease showed that T146 is located in the loop connecting the proposed $\mathrm{C} 2$ and D2 $\beta$-strands and $\mathrm{H} 167$ is located in the E2 strand similar to $3 \mathrm{C}$ protease. These residues are also conserved in NIa proteases across the genera of the Potyviridae. In the earlier simulation studies with TEV NIa protease, Dougherty et al. [11] had proposed a similar role for H167 in NIa protease. Earlier studies on TuMV NIa protease had demonstrated that mutation of H167 abolished the protease activity [18]. However, this is the first time that T146 is implicated in the P1 Gln binding function. The determination of the three dimensional structure of the NIa protease is important to confirm these mutational data.

\section{Acknowledgements}

This research was supported by Rallis India Ltd. We thank Mr. B. P. Srinivas for his assistance in the mutational studies. Mr. Jomon Joseph is a recipient of CSIR fellowship. We thank DBT for providing the DNA sequencing facility and Ms. Savitha for assistance in DNA sequencing.

\section{References}

1. Allaire M, Chernaia MM, Malcolm BA, James MNG (1994) Picornaviral 3C cysteine proteinases have a fold similar to chymotrypsin-like serine proteinases. Nature 369: $72-76$

2. Bazan JF, Fletterick RJ (1988) Viral cysteine proteases are homologous to the trypsinlike family of serine proteases: Structural and functional implications. Proc Natl Acad Sci USA 85: 7872-7876

3. Bazan JF, Fletterick RJ (1989) Comparative analysis of viral cysteine protease structural models. FEBS Lett 249: 5-7

4. Carrington JC, Dougherty WG (1987) Small nuclear inclusion protein encoded by a plant potyvirus genome is a protease. J Virol 61: 2540-2548

5. Carrington JC, Cary SM, Dougherty WG (1988) Mutational analysis of tobacco etch virus polyprotein processing: cis and trans proteolytic activities of polyproteins containing the 49-kilodalton proteinase. J Virol 62: 2313-2320

6. Carrington JC, Dougherty WG (1988) A viral cleavage site cassette: identification of amino acid residues in tobacco etch virus polyprotein processing. Proc Natl Acad Sci USA 85 : $3391-3395$ 
7. Carrington JC, Cary SM, Parks TD, Dougherty WG (1989) A second proteinase encoded by a plant potyvirus genome. EMBO J 8: 365-370

8. Cheah K-C, Leong LE-C, Porter AG (1990) Site-directed mutagenesis suggests close functional relationship between a human rhinovirus $3 \mathrm{C}$ cysteine protease and cellular trypsin-like serine proteases. J Biol Chem 265: 7180-7187

9. Chou PY, Fasman GD (1978) Empirical predictions of protein conformation. Ann Rev Biochem 47: 251-276

10. Dougherty WG, Carrington JC, Cary SM, Parks TD (1988) Biochemical and mutational analysis of a plant virus polyprotein cleavage site. EMBO J 7: 1281-1287

11. Dougherty WG, Parks TD, Cary SM, Bazan JF, Fletterick RJ (1989) Characterization of the catalytic residues of the tobacco etch virus $49-\mathrm{kDa}$ proteinase. Virology 172: 302-310

12. Dougherty WG, Semler BL (1993) Expression of virus-encoded proteinases: functional and structural similarities with cellular enzymes. Microbiol Rev 57: 781-822

13. Garcia JA, Riechmann JL, Teresa M, Lain S (1989) Proteolytic activity of the plum pox potyvirus NIa-protein on excess of natural and artificial substrates in Escherichia coli. FEBS Lett 257: 269-273

14. Garcia JA, Lain S, Cervera MT, Riechmann JL, Martin MT (1990) Mutational analysis of plum pox potyvirus polyprotein processing by the NIa protease in Escherichia coli. J Gen Virol 71: 2773-2779

15. Gorbalenya AE, Donchenko AP, Koonin EV, Blinov VM (1989) Cysteine proteases of positive strand RNA viruses and chymotrypsin-like serine proteases: a distinct superfamily with a common structural fold. FEBS Lett 243: 103-114

16. Joseph J, Savithri HS (1999) Determination of 3'-terminal nucleotide sequence of pepper vein banding virus RNA and expression of its coat protein in Escherichia coli. Arch Virol 144: 1679-1687

17. Kim D-H, Park YS, Kim SS, Lew J, Nam HG, Choi KY (1995) Expression, purification and identification of a novel self-cleavage site of the NIa C-terminal $27 \mathrm{kDa}$ protease of turnip mosaic potyvirus C5. Virology 213: 517-525

18. Kim D-H, Hwang DC, Kang BH, Lew J, Choi KY (1996) Characterization of NIa protease from turnip mosaic potyvirus exhibiting a low-temperature optimum catalytic activity. Virology 221: 245-249

19. Landt O, Grunert HP, Hahn U (1990) A general method for rapid site-directed mutagenesis using polymerase chain reaction. Gene $96: 125-128$

20. Matthews DA, Smith WW, Ferre RA, Condon B, Budahazi G, Sisson W, Villafranca JE, Janson CA, McElroy HE, Gribscov CL, Worland S (1994) Structure of human rhinovirus 3C protease reveals a trypsin-like polypeptide fold, RNA-binding site, and means for cleavage precursor polyprotein. Cell 77: 761-771

21. Parks TD, Dougherty WG (1991) Substrate recognition by the NIa proteinase involves multiple domains: characterization using genetically engineered hybrid proteinase molecules. Virology 182: 17-27

22. Parks TD, Howard ED, Wolpert TJ, Arp DJ, Dougherty WG (1995) Expression and purification of a recombinant tobacco etch virus NIa proteinase; biochemical analyses of the full-length and a naturally occurring truncated proteinase form. Virology 210: 194-201

23. Ravi KS, Joseph J, Nagaraju N, Krishna Prasad S, Reddy HR, Savithri HS (1997) Characterization of a pepper vein banding virus from chili pepper in India. Plant Dis 81: 673-676

24. Riechmann JL, Lain S, Garcia JA (1992) Highlights and prospects of potyvirus molecular biology. J Gen Virol 73: 1-16 
25. Sambrook J, Fritsch EF, Maniatis T (1989) Molecular cloning: A laboratory manual, 2nd ed. Cold Spring Harbor Laboratory Press, Cold Spring Harbor

26. Sanger F, Nicklen S, Coulson AR (1977) DNA sequencing by chain termination inhibitors. Proc Natl Acad Sci USA 74: 5463-5467

27. Semler BL, Hanecak R, Dorner LF, Anderson CW, Wimmer E (1983) Poliovirus RNA synthesis in vitro: structural elements and antibody inhibition. Virology 126: 624-634

28. Stanway G, Hughes PJ, Mountford RC, Minor PD, Almond JW (1984) The complete nucleotide sequence of a cold virus: human rhinovirus 14. Nucleic Acids Res 12: 78597875

29. Verchot J, Koonin EV, Carrington JC (1991) The 35-kDa protein from the N-terminus of a potyviral polyprotein functions as a third virus-encoded proteinase. Virology 185: $527-535$

Authors' address: Dr. H. S. Savithri, Department of Biochemistry, Indian, Institute of Science, Bangalore 560 012, India.

Received April 7, 2000 